\title{
Seasonal and spatial variation in the energetics of the invasive clam Corbula amurensis in the upper San Francisco Estuary
}

\author{
Nathan A. Miller ${ }^{1, *}$, Jonathon H. Stillman ${ }^{1,2}$ \\ ${ }^{1}$ Romberg Tiburon Center, San Francisco State University, 3150 Paradise Drive, Tiburon, California 94920, USA \\ ${ }^{2}$ Department of Integrative Biology, University of California, Berkeley, 1005 Valley Life Sciences, Bldg \#3140, Berkeley, \\ California 94720-2140, USA
}

\begin{abstract}
Predicting the impacts of invasive species on native communities requires an understanding of the energy requirements of the community members and the strength and direction of energy flows within the ecosystem. The Asian clam Corbula amurensis invaded the San Francisco Estuary (SFE) in 1986 and is implicated in the decline of native fish species, by diverting pelagic productivity to the benthos through filter feeding. We sought to characterize how energetic demands of $C$. amurensis respond to natural seasonal and spatial variation in salinity, and how this response may be influenced by variation in temperature and food availability. We found that metabolic rates of $C$. amurensis vary seasonally and spatially within the estuary, but temperature, salinity, and food availability explain little of the variability. The insensitivity of metabolism to salinity suggests a re-evaluation of the importance of this environmental factor in determining the distribution of $C$. amurensis in the SFE. Though C. amurensis did hyperosmoregulate under low salinity conditions, the potential costs of this activity were not associated with changes in metabolic rate or energy stores (glycogen). Current knowledge suggests that under natural food, temperature, and salinity regimes in the SFE, the distribution of adult $C$. amurensis is not likely a consequence of the energetic costs of salinity tolerance. However, the role that food availability plays in modulating salinity tolerance, especially at different temperatures, deserves additional attention.
\end{abstract}

KEY WORDS: Bivalves - Salinity · Osmoregulation · Metabolism · Temperature · Glycogen · Foodweb

\section{INTRODUCTION}

Invasive species have the potential to alter food web dynamics in invaded ecosystems. In shallow water estuaries, the presence of non-native benthic filter-feeding bivalves may dramatically alter pelagic primary and secondary productivity by diverting resources from the water column to the benthos (Cloern 1982, Cole et al. 1992, Thompson et al. 2008). The strength of the benthic-pelagic coupling depends, in part, on the energy requirements and rates of energy use of the dominant benthic species (Newell 2004). In estuarine systems, salinity and salinity variation are significant drivers of individual energy budgets (Shumway \& Koehn 1982, Marsden 2004) and vary naturally (e.g. seasonal changes in freshwater flow, large-scale climatic oscillations) and as a result of anthropogenic modifications of freshwater flow (e.g. fresh water management). Predicting the impact of invasive species on native communities and how the distribution of native and invasive species may respond to environmental change requires 
accurate estimates of the strength and direction of energy flow (as well as its sensitivity to perturbation) through an ecosystem (Dukes \& Mooney 2004, Thompson 2005). A prerequisite to such analyses is an accurate characterization of the energetics of the dominant players within the ecosystem and their individual sensitivities to environmental change.

The Asian or overbite clam Corbula amurensis was first discovered in San Francisco Estuary (SFE) in October 1986, and by 1988 reached densities exceeding $10000 \mathrm{~m}^{-2}$ (Carlton et al. 1990). By 1990, C. amurensis was established as the dominant species in benthic communities throughout the estuary at a wide range of salinities and temperatures (Nichols et al. 1990). Adult $C$. amurensis have a wide salinity tolerance ( $~ 0$ to 30, Nicolini \& Penry 2000) and consequently persist in the northern SFE year round.

The northern SFE is a partially mixed estuary formed at the confluence of California's 2 longest rivers, the Sacramento and San Joaquin. The SFE exhibits a Mediterranean climate with high local freshwater inputs from runoff and rain in winterspring, and little precipitation between June and October. Freshwater inputs are further influenced by mountain snowmelt and upstream water exports for agricultural and residential household use. Temperatures and salinities within the system are dynamic, but temperatures may range from $\sim 5-25^{\circ} \mathrm{C}$ and salinities from 0-25 (Wilkerson et al. 2006). Historically, summer phytoplankton blooms were common, but since the arrival of Corbula amurensis, phytoplankton abundance has been consistently low and chlorophyll levels in the estuary are typically $\sim 3-4 \mu \mathrm{g} \mathrm{l^{-1 }}$ (Wilkerson et al. 2006).

Filter feeding by Corbula amurensis is thought to be the cause of a dramatic reduction in summertime phytoplankton abundance in the shallow brackish northern parts of the SFE (Alpine \& Cloern 1992). In addition to phytoplankton, C. amurensis is capable of grazing on bacterioplankton (Werner \& Hollibaugh 1993), copepod nauplii (Kimmerer et al. 1994), and microzooplankton (Greene et al. 2011), and is thus able to graze on the entire bottom of the food web. A decline in abundance of 3 common estuarine copepod species coincided with the invasion of C. amurensis (Kimmerer et al. 1994), probably through a combination of predation and competition for phytoplankton and microzooplankton food. Concurrent declines in the abundance of higher trophic level pelagic taxa including delta smelt Hypomesus transpacificus (Feyrer et al. 2007, Sommer et al. 2007, Nobriga et al. 2008), mysid shrimp Neomysis mercedis (Orsi \& Mecum 1996), longfin smelt Spirinchus thaleichthys (Kimmerer 2002), and striped bass Morone saxatilis (Kimmerer et al. 2009) have occurred, all presumably due to food limitation.

Bivalve energetics is shown to respond to variation in temperature, salinity, and food availability. Metabolic rates in bivalves, as in other ectotherms, exhibit a positive relationship with temperature (Hutchinson \& Hawkins 1992, Anestis et al. 2007, Sarà et al. 2008). The effect of salinity on metabolic rate varies between species, but tends to be positive (Navarro 1988, Hutchinson \& Hawkins, 1992, Sarà et al. 2008), though metabolic rates may be highest at salinity extremes and may be lowest under fluctuating, intermediate salinities (Paganini et al. 2010). Reduced metabolic rates at low salinities are attributed to prolonged valve closure in some species (Berger \& Kharazova 1997, Anestis et al. 2007). Modulated through valve closure, low salinity stress may have important consequences as anaerobic metabolism (Anestis et al. 2007) and reduced time spent feeding may lead to reduced energy stores (Marsden 2004, Sara et al. 2008). Additionally, higher metabolic rates at higher temperatures may shorten the potential duration of valve closure (due to accumulation of waste products and declining energy stores), thereby influencing low salinity tolerance (Hutchinson \& Hawkins 1992, Marsden 2004). There is also some evidence that exposure to low salinity limits the heat shock response of Corbula amurensis to heavy metals, possibly due to energy limitation and competition between heat shock and osmoregulatory demands (Werner \& Hinton 1999, Werner \& Hinton 2000, Werner 2004). Given the dynamic nature of the SFE, an accurate estimate of energy flow through $C$. amurensis must consider how salinity, along with temperature and food availability, may influence energy storage and expenditure.

Our aim was to characterize the metabolic physiology of Corbula amurensis across seasons in the upper SFE, capturing their response to the natural temporal and spatial variation in environmental temperature, salinity, and food availability. We measured clam metabolic rates, tissue osmolarities and glycogen energy stores to quantify variation in energy expenditure in the field from October 2010 to October 2011. Measurements of chlorophyll $a$ concentration at each sampling site provided a measure of variation in food availability. These data were used to estimate how the impact of $C$. amurensis on the northern SFE food web may vary seasonally and as a consequence of managed freshwater inputs. 


\section{MATERIALS AND METHODS}

\section{Field collections}

Corbula amurensis (5.8-20.2 $\mathrm{mm}$ shell length) were collected approximately once per month from October 2010 to October 2011 at 4 fixed sampling sites within Suisun Bay, using the RV 'Questuary' (Fig. 1). The sites were chosen to encompass the annual range in salinities that $C$. amurensis experiences in this region, with Site 1 being the most saline and Site 4 the most fresh. At each site, water samples were collected approximately $0.5 \mathrm{~m}$ above the sediment surface using a Seabird carousel water sampler with an attached CTD (recording bottom salinity and temperature). Water from each site was prefiltered through a $100 \mu \mathrm{m}$ mesh filter before three 11 volumes of water were vacuum filtered through pre-combusted $90 \mathrm{~mm}$ Millipore GF/F filters. The filters were immediately frozen on dry ice and stored at $-80^{\circ} \mathrm{C}$ until analyzed for chlorophyll a (chl a). The filtrate was used for the metabolic rate experiments.

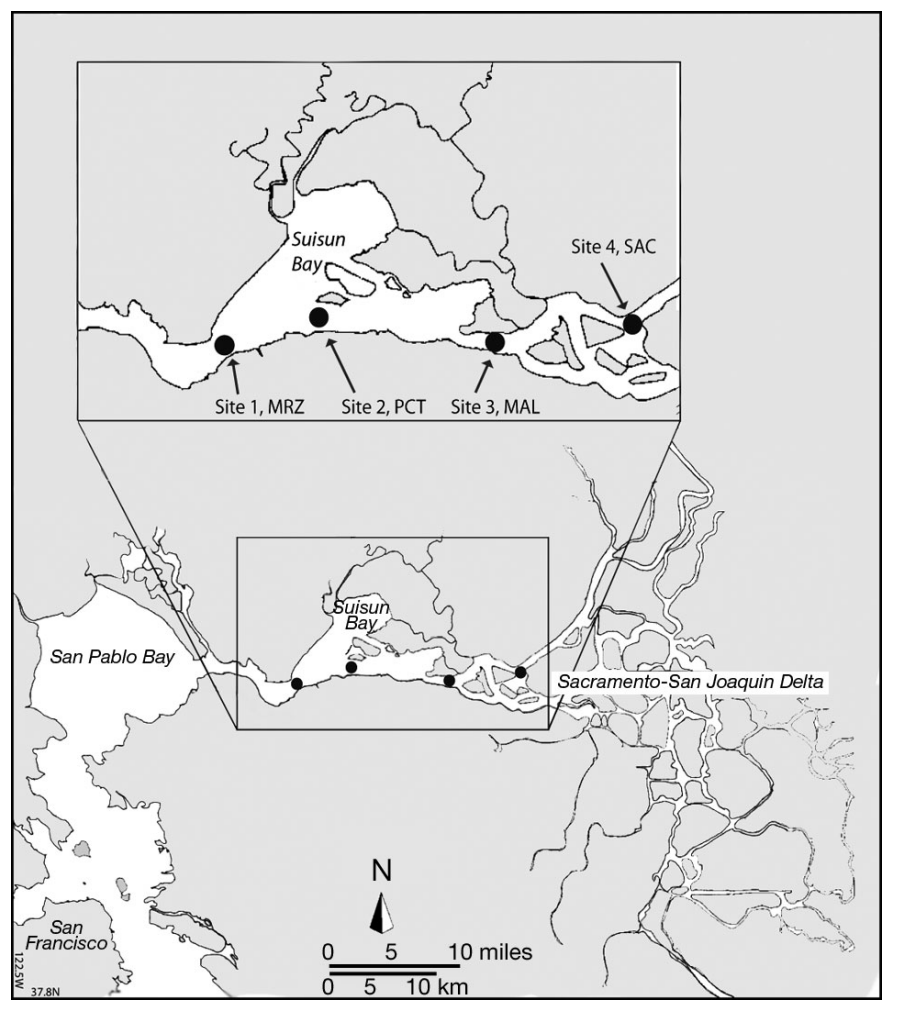

Fig. 1. The San Francisco Bay Estuary. Corbula amurensis and water sample collection sites are shown on inset (scale in statute miles). Site 1 (MRZ): $38^{\circ} 2.8^{\prime} \mathrm{N}, 122^{\circ} 5.9^{\prime} \mathrm{W}, \sim 56$ river $\mathrm{km}$; Site 2 (PCT, 'intermediate site'): $38^{\circ} 3.6^{\prime} \mathrm{N}, 122^{\circ} 2.1^{\prime} \mathrm{W}, \sim 65$ river $\mathrm{km}$; Site 3 (MAL): $38^{\circ} 2.6^{\prime} \mathrm{N}, 121^{\circ} 54.4^{\prime} \mathrm{W}, \sim 73$ river $\mathrm{km}$; Site 4 (SAC): $38^{\circ} 3.5^{\prime} \mathrm{N}, 121^{\circ} 48^{\prime} \mathrm{W}$, $\sim 85$ river $\mathrm{km}$
Following water sampling, clams were collected from each site using a Van Veen sediment grab. Clams were separated from sediment using a $\sim 6 \mathrm{~mm}$ hardware cloth sieve. Approximately 50-100 clams were collected from each site and kept in filtered water at their collection salinity (see Fig. 2B). An additional 100 clams were collected from sampling Site 2, frozen on dry ice, and stored at $-80^{\circ} \mathrm{C}$ for subsequent analyses of tissue osmolarity and glycogen content.

To address some of the salinity dynamism in this system we calculated the mean bottom water salinity at each sampling site during the $6 \mathrm{~h}$ prior to our sampling (data from the California Data Exchange Center [CDEC]; http://cdec.water.ca.gov/). The time scale over which energy is processed in these clams is not known, but in other clams gut passage times (representing the rate at which food is made available for metabolism) of 2-6 h have been measured (Bricelj et al. 1984). Energy metabolism may integrate over environmental variables, such as salinity, on a similar timescale. Consequently, we used the mean salinity during the $6 \mathrm{~h}$ prior to our sampling as an alternative predictor of clam metabolism in some regression analyses.

\section{Metabolic rate measurements}

At each site 10 clams were immediately (in the field, and within 10 min of being removed from the sediment) transferred to $30 \mathrm{ml}$ glass scintillation vials containing $16 \mathrm{~g}$ of clean aragonite sand and the site-specific GF/F filtered water. Planar optode spots (diameter $0.5 \mathrm{~cm}$; Presens, Germany) had been previously secured to the inside of each vial and calibrated in the laboratory using $\mathrm{O}_{2}$-saturated and $\mathrm{O}_{2}$-free San Francisco Bay water prior to each sampling cruise. Each vial was filled with water and sealed with a screw lid, ensuring no bubbles were trapped within the vial. The cap of each vial was outfitted with a magnetic 'propeller' so that when placed on a laboratory stir-plate the propeller slowly turned, mixing the water within the vial but not disturbing the sand. The vials were submersed in a temperature-controlled water bath (ThermoScientific RTE7) held at the site-specific water temperature. The oxygen saturation of the water within individual vials was measured at $10 \mathrm{~min}$ intervals, for 70 min, using a Fibox3 mini oxygen sensor (Presens, Germany). Specimens were then transported in aerated respirometry vials to the laboratory, where they remained overnight. 
The following day, the same metabolic rate measurements were repeated on the same individuals. The specimens had been left without food overnight, to quantify the degree to which metabolism associated with digestion (known as specific dynamic action, or SDA) influenced Day 1 metabolic rates. Following the second metabolic rate determination, the clams were dissected from their shells, weighed, dried at $60^{\circ} \mathrm{C}$ for $24 \mathrm{~h}$ and reweighed to determine both wet and dry shell-free tissue mass. All metabolic rates were expressed in $\mu \mathrm{mol} \mathrm{O}_{2}$ consumed per gram shell-free dry mass (SFDW) per hour.

\section{Chl $a$ analysis}

Chl a was determined by in vitro fluorometry (Arar \& Collins 1992) using a Turner Designs Model 10 fluorometer, calibrated with commercially available chl $a$ (either Sigma Chemical Company or Turner Designs) on samples filtered onto Millipore $90 \mathrm{~mm}$ GF/F filters and extracted with $90 \%$ acetone.

\section{Tissue osmolarity}

Variation in tissue osmolarity over the course of the sampling period was assessed using frozen clams collected from a single, intermediate sampling site (Site 2 PCT, Fig. 1) as sufficient clams could be collected for analyses from this site with minimal effort. For each sampling date, 10 whole clams were dissected and homogenized in a 10-fold dilution of deionized water with Kontes-Duall ground glass homogenizers. The homogenate was centrifuged for $30 \mathrm{~min}$ at $16100 \times \mathrm{g}$. The supernatant was transferred to a prewashed $(1 \times 500 \mu l 0.1 \mathrm{~N} \mathrm{NaOH}$, followed by $2 \times 500 \mu$ l Millipore filtered water) centrifugal filter unit (Amicon Ultra $3 \mathrm{kDa}$ ) and centrifuged at $16100 \times g$ for $25 \mathrm{~min}$ to remove large molecular weight compounds that interfered with the osmometry (but did not contribute to the solution's osmolarity). Tissue osmolarity was determined in triplicate for each clam using an Osmette freeze-point depression osmometer (Precision Systems, USA).

\section{Whole clam glycogen content}

Total clam glycogen was approximated from free glucose concentrations following an enzymatic digestion of glycogen into glucose using amyloglucosidase, following the method of Richards et al.
(2002). Whole, frozen clams collected from Site 2, (Fig. 1) were dissected from shells, weighed to the nearest $0.1 \mathrm{mg}$, and placed in $2 \mathrm{ml}$ tubes. To each tube, $0.5 \mathrm{ml}$ of $30 \% \mathrm{KOH}$ was added, and the tubes were placed in a $98^{\circ} \mathrm{C}$ water bath until the tissue dissolved $(20 \mathrm{~min})$. The tubes were removed from the water bath, cooled, and $250 \mu$ l of saturated sodium sulfate, and $1.0 \mathrm{ml} 95 \%$ ethanol were added, mixing by vortex between each addition. The tubes were returned to the $98^{\circ} \mathrm{C}$ water bath until the contents just boiled, before being cooled to room temperature and centrifuged at $3000 \mathrm{rpm}$ for $5 \mathrm{~min}$. The resulting supernatant was discarded, the pellet resuspended in $1.0 \mathrm{ml}$ distilled water $\left(\mathrm{dH}_{2} \mathrm{O}\right)$, and $2.0 \mathrm{ml}$ of $95 \%$ ethanol added. The tubes were returned to the $98^{\circ} \mathrm{C}$ water bath until the contents just boiled and again centrifuged at $800 \times g$ for $5 \mathrm{~min}$. The supernatant was discarded and the remaining ethanol evaporated. The remaining pellet was resuspended in $600 \mu \mathrm{l}$ of $\mathrm{dH}_{2} \mathrm{O}$.

For each sample, $500 \mu \mathrm{l}$ of the digestate (above) was added to a $1.5 \mathrm{ml}$ tube along with $750 \mu \mathrm{l}$ of acetate buffer $(0.29 \mathrm{M}$ glacial acetic acid, $0.12 \mathrm{M}$ sodium acetate, $\mathrm{pH} 4.8$ ). The glycogen in each sample tube was digested to glucose by adding $20 \mu \mathrm{l}$ amyloglucosidase (Sigma, A7095). The tubes were incubated at $37^{\circ} \mathrm{C}$ for $2 \mathrm{~h}$, at which point $25 \mu \mathrm{l}$ of $70 \%$ perchloric acid was added to each tube to stop the digestion. The additions to each tube (the amyloglucosidase at the beginning and the percloric acid at the end) were staggered by $10 \mathrm{~s}$ between tubes to ensure that the enzymatic digestion in each tube took place over an identical length of time. The extract was neutralized with $80 \mu \mathrm{l}$ of $3 \mathrm{M} \mathrm{K}_{2} \mathrm{CO}_{3}$, and the perchlorate salt precipitated by centrifuging at $800 \times g$ for $5 \mathrm{~min}$. The supernatant was removed to another $1.5 \mathrm{ml}$ tube, and diluted $1: 20$ or $1: 22$ with $\mathrm{dH}_{2} \mathrm{O}$.

The free glucose in the extract was measured by enzymatic spectrophotometric assay in 96-well microplates. To each well, $20 \mu \mathrm{l}$ of extract along with $100 \mu \mathrm{l}$ glucose assay buffer (final conc: $30.3 \mathrm{mM} \mathrm{NaH}_{2} \mathrm{PO}_{4}$ $\mathrm{MgCl}_{2}$ buffer [80 $\left.\mathrm{mM} \mathrm{NaH}_{2} \mathrm{PO}_{4}, 4.3 \mathrm{mM} \mathrm{MgCl}_{2}\right], 0.62$ mM $\beta$ NADP [Sigma, N7505], $0.59 \mathrm{mM}$ ATP [Sigma, A7699], and $1.54 \mathrm{U} \mathrm{ml}^{-1}$ glucose 6-phosphate dehydrogenase [Sigma, G8404]) was added. The microplate was mixed, incubated at $37^{\circ} \mathrm{C}$ for $5 \mathrm{~min}$, and mixed again before an initial absorbance at $340 \mathrm{~nm}$ was measured in a Tecan Infinite 200 Microplate Spectrophotometer. Each well then received $2 \mu \mathrm{l}$ hexokinase working stock $(5 \mu \mathrm{l}$ hexokinase [Sigma,

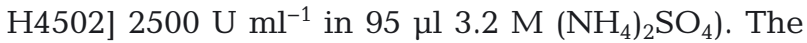
microplate was mixed, incubated at $37^{\circ} \mathrm{C}$ for $20 \mathrm{~min}$, mixed again, and a second absorbance reading was 
made $(340 \mathrm{~nm})$. The difference in absorbance before and after the addition of the hexokinase is proportional to the free glucose in the extract. Total clam free glucose was presented as mM glucose per clam corrected for clam mass.

\section{Predicted clam clearance rates}

We used metabolic rates to determine the clams' impact on the pelagic ecosystem by roughly calculating the filtration rate, and therefore the amount of water a clam must filter to meet its energetic demands. Using the clam metabolic rates that we observed in this study (both Day 1 and Day 2) and assuming a respiratory quotient $(\mathrm{RQ})$ of 1 (converting oxygen required to carbon required) we expressed the maximum Corbula amurensis metabolic rates in $\mu \mathrm{g} \mathrm{C} \mathrm{g}{ }^{-1} \mathrm{~h}^{-1}$. The carbon:chlorophyll ratio in Suisun Bay is roughly 20 (Kimmerer et al. 2012), allowing an estimation of the amount of chlorophyll a clam will require $\left(\mu \mathrm{g}\right.$ chl a g ${ }^{-1} \mathrm{~h}^{-1}$ ). Using measured chlorophyll concentrations from this study, we calculated the volume of water a clam must filter (at $100 \%$ efficiency) to meet its metabolic demands $\left(\mathrm{g} \mathrm{g}^{-1} \mathrm{~h}^{-1}\right)$. To improve comparisons with other datasets we have converted our values, originally normalized to shellfree dry weight (SFDW), into ash free dry weight $(\mathrm{AFDW})$ using the conversion $(\mathrm{AFDW}=0.83 \times$ SFDW) from Ricciardi \& Bourget (1998). In addition, all metabolic rates were expressed at a common temperature $\left(15^{\circ} \mathrm{C}\right.$ ) using a $Q_{10}$ of 2 (the $Q_{10}$ of metabolic rate observed in this study).

\section{Statistical analyses}

All statistical analyses were carried out using the $\mathrm{R}$ statistical program (v. 2.14.2). Main effects and interaction effects of temperature, salinity, and chlorophyll concentration on clam metabolic rates were tested using multiple linear regression models. Residual errors were tested for normality using QQnormality plots. Significant heteroscedasticity in regression plots was visually identified and tested for using a Bruesch-Pagan test (ncvTest, package car). Heteroscedasticity leaves regression parameters unbiased, but does lead to biased estimates of their standard errors, the associated $t$-values, and the statistical interpretation of the data. Therefore, when significant heteroscedasticity was identified, a White's correction was used to generate a White's robust variance-covariance matrix (hccm, package car). The coeftest function in the sandwich package was then used to produce accurate $t$-values and p-values based upon the corrected variance-covariance matrix. All mentions of 'significance' are in reference to the results of a particular statistical test using an $\alpha$ of 0.05 unless otherwise stated. Regression model comparisons were made using the $A I C$ function in the stats package. Models with lower AIC values were considered to better fitting.

\section{RESULTS}

Environmental conditions within the estuary (bottom water temperature, salinity, and chl a values) all showed seasonal fluctuations. Water temperature fluctuated nearly $14^{\circ} \mathrm{C}$ over the sampling period, but was identical across all sites on any particular sampling date (Fig. 2A). Salinity also showed considerable variation across the sampling period though the degree of variability depended upon sampling site (Fig. 2B). Downstream sampling sites (Sites 1 and 2) showed much greater salinity variation, while the most upstream site (Site 4) remained nearly fresh water for much of the year. Chl a concentration increased during the sampling period (Fig. 2C) and peaked by mid-summer ( Day of Year 145) with elevated levels persisting into fall 2011 at the most upstream sites (Fig. 2C, Sites 3 and 4).

The metabolic rates of clams immediately following collection (Day 1) varied across the sampling period and across sampling sites (Fig. 2D). Day 1 metabolic rates show a general seasonal pattern with declines through the fall and winter (first 5 sampling dates) and increases through the summer. Metabolic rates on Day 2 followed the same general seasonal pattern (Fig. 2E) and metabolic rates on both days were significantly positively correlated with one another (Spearman's rank correlation, $\rho=0.47, \mathrm{p}<$ 0.001). There was no clear pattern for Day 1 metabolic rates to be higher or lower than Day 2, despite the fact that Day 1 clams are presumed to have recently fed. To aid in comparisons to other studies, we report that clams collected during this study had a shell length that ranged from $8-16 \mathrm{~mm}$, a range of shell width from $5.5-10.5 \mathrm{~mm}$, and a range of shell heights from $2.8-6.5 \mathrm{~mm}$.

When analyzed across all sampling sites, variation in metabolic rate increased positively with temperature and negatively with salinity for both measurement days, though the relationship shows considerable scatter (Figs. S1 \& S2 in the supplement at www. int-res.com/articles/suppl/m476p129_supp.pdf). A 

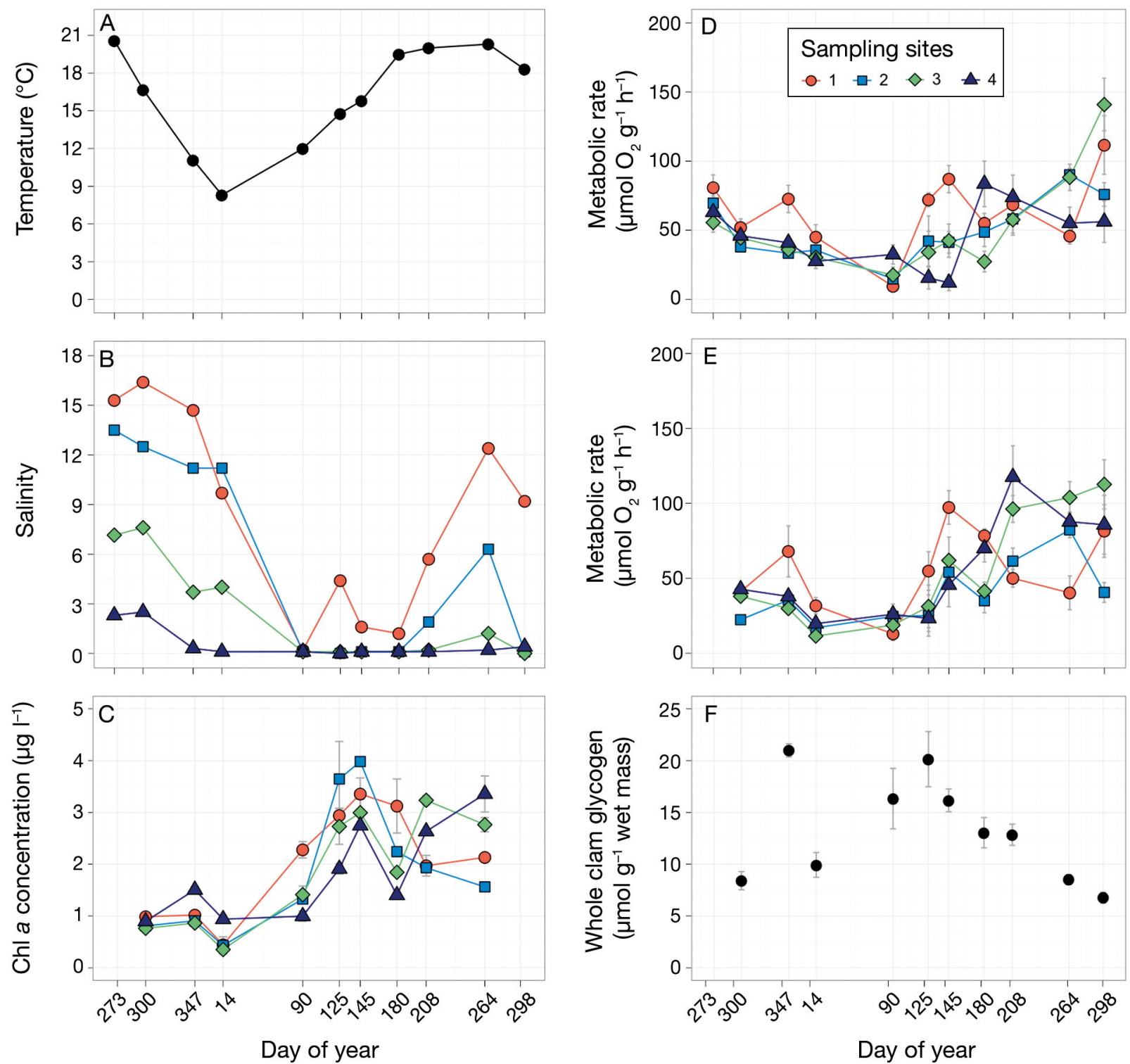

Fig. 2. Environmental parameters and Corbula amurensis physiological characteristics as a function of the day of the year from each sampling site. Environmental parameters: (A) temperature, (B) salinity, and (C) chlorophyll a concentration. All environmental measurements or samples were taken at the time of clam collection. Physiological characteristics: metabolic rates measured (D) on the day of collection (Day 1) and (E) on the same clams one day following collection (Day 2); (F) whole clam glycogen content. Data are mean \pm SE. Sample sizes for each site and date: chlorophyll analysis: $\mathrm{n}=3$ or 4 GF/F filters, metabolic rates: $\mathrm{n}=10$ clams, glycogen content: $\mathrm{n}=8$ clams

multiple linear regression with sampling site as a covariate and using a corrected variance-covariance matrix to account for the heteroscedasticity in the data found a significant interactive effect of temperature and salinity on Day 1 metabolic rates $(t=-3.00$, $\mathrm{p}<0.01$ ) (Table 1, Figs. S1 \& S2 in the supplement). Separating the Day 1 analysis by sampling site identified a significant temperature-salinity interaction for Site $3(t=-2.1727, \mathrm{p}=0.03)$ and a significant difference in the regression intercepts between Sites 1 and $2(t=-2.1, \mathrm{p}=0.04)$. Viewed on a site-by-site basis the relationships between temperature or salinity and metabolic rate exhibit considerable scatter, suggesting that though some relationships are statistically significant, they may not explain enough of the variability (Day 1: adj. $\mathrm{R}^{2}=0.17$; Day 2 : adj. $\mathrm{R}^{2}=$ 0.3 ) or may be too site-specific to have broad predictive utility (Figs. S1A \& S2A in the supplement).

For Day 2 there was a significant interactive effect of temperature and salinity on metabolic rates across 
Table 1. Multiple linear regression analyses of the effect of temperature (Temp), salinity (Sal) and chlorophyll a (Chl a) concentration on Corbula amurensis metabolic rate

\begin{tabular}{|c|c|c|c|c|}
\hline & Estimate & SE & $t$ & $\mathrm{p}$ \\
\hline \multicolumn{5}{|l|}{ Day 1} \\
\hline \multicolumn{5}{|c|}{$\mathrm{VO}_{2} \sim$ Temp $\times$ Sal $\left(\right.$ Adj. $\mathrm{R}^{2}=0.14$, AIC $\left.=3740\right)$} \\
\hline Intercept & -19.54 & 7.57 & -2.58 & 0.01 \\
\hline Temp & 4.41 & 0.52 & 8.46 & $<0.001$ \\
\hline Sal & 4.07 & 1.06 & 3.84 & $<0.001$ \\
\hline Temp:Sal & -0.2 & 0.07 & -3.00 & $<0.01$ \\
\hline \multicolumn{5}{|c|}{$\mathrm{VO}_{2} \sim \mathrm{Temp} \times \mathrm{Sal} \times \mathrm{Chl} a\left(\mathrm{Adj} . \mathrm{R}^{2}=0.19, \mathrm{AIC}=2934\right)$} \\
\hline Intercept & 0.22 & 20.23 & 0.01 & 0.99 \\
\hline Temp & 3.00 & 1.61 & 1.86 & 0.06 \\
\hline Sal & 0.45 & 2.54 & 0.18 & 0.86 \\
\hline Chl a & -12.68 & 12.48 & -1.02 & 0.31 \\
\hline Temp:Sal & -0.19 & 0.18 & -1.06 & 0.29 \\
\hline Temp:Chl a & 0.68 & 0.81 & 0.84 & 0.40 \\
\hline Sal:Chl a & 7.78 & 2.40 & 3.24 & $<0.01$ \\
\hline Temp:Sal:Chl a & -0.30 & 0.14 & -2.22 & $<0.05$ \\
\hline \multicolumn{5}{|l|}{ Day 2} \\
\hline \multicolumn{5}{|c|}{$\mathrm{VO}_{2} \sim$ Temp $\times$ Sal $\left(\right.$ Adj. $\mathrm{R}^{2}=0.25$, AIC $\left.=3740\right)$} \\
\hline Intercept & -49.38 & 8.33 & -5.93 & $<0.001$ \\
\hline Temp & 6.55 & 0.56 & 11.62 & $<0.001$ \\
\hline Sal & 6.24 & 1.46 & 4.27 & $<0.001$ \\
\hline Temp:Sal & -0.43 & 0.10 & -4.45 & $<0.001$ \\
\hline \multicolumn{5}{|c|}{$\mathrm{VO}_{2} \sim \operatorname{Temp} \times \mathrm{Sal} \times \mathrm{Chl}$ a $\left(\mathrm{Adj} . \mathrm{R}^{2}=0.36, \mathrm{AIC}=2975\right)$} \\
\hline Intercept & 31.00 & 15.97 & 1.94 & 0.05 \\
\hline Temp & 0.01 & 1.18 & 0.01 & 0.99 \\
\hline Sal & -5.12 & 2.23 & -2.30 & $<0.05$ \\
\hline Chl $a$ & -43.16 & 11.09 & -3.89 & $<0.001$ \\
\hline Temp:Sal & 0.23 & 0.14 & 1.62 & 0.11 \\
\hline Temp:Chl a & 3.15 & 0.67 & 4.69 & $<0.001$ \\
\hline Sal:Chl a & 12.13 & 3.24 & 3.74 & $<0.001$ \\
\hline Temp:Sal:Chl a & -0.64 & 0.17 & -3.83 & $<0.001$ \\
\hline
\end{tabular}

all sampling sites $(t=-4.45, \mathrm{p}<0.001$, Table 1$)$. When analyzed by sampling site, Sites 1 and 2 exhibited significant interactions between salinity and temperature (Site 1: $t=-2.74, \mathrm{p}<0.01$, Site 2: $t=2.74, \mathrm{p}<$ $0.01)$ (Figs. S1B \& S2B in the supplement). The significant interaction between salinity and temperature is less apparent on Day 1, but visually apparent on Day 2 (Fig. S1), as higher metabolic rates are only found at high temperatures and low salinities.

The mean salinity during the $6 \mathrm{~h}$ period prior to specimen collection was correlated with salinity at the time of collection $\left(\mathrm{S}_{0}=0.68 \times \mathrm{S}_{6}+0.4, \mathrm{R}^{2}=0.74\right.$ where $\mathrm{S}_{0}=$ sampling salinity, $\mathrm{S}_{6}=$ mean salinity during $6 \mathrm{~h}$ prior to sampling), and tended to be higher. Models with either measure of salinity had similar residual standard errors, demonstrating that mean prior salinity was not any better at explaining patterns in Corbula amurensis metabolism (collection salinity model RSE: 35.44 on $359 \mathrm{df}$; prior salinity model RSE: 35.0 on $359 \mathrm{df}$ ).
Considering chl a as an additional explanatory variable provided evidence of a significant 3-way interaction between temperature, salinity, and chlorophyll concentration for both Day 1 and Day 2 metabolic rates when considering all sites (Day 1: $t=$ $-2.22, \mathrm{p}<0.05$, Day 2: $t=-3.83, \mathrm{p}<0.001$, Table 1). Lower AIC values for models including the chlorophyll term (AIC: Day 1, 3740 vs. 2934; Day 2, 3439 vs. 2975) suggest its inclusion in the analysis is warranted even though the proportion of the variance explained by these models was still low (Day 1: adj. $\mathrm{R}^{2}=0.19$, Day 2 : adj. $\mathrm{R}^{2}=0.36$, Table 1 ). High chlorophyll concentrations tend to be associated with higher metabolic rates (Fig. S3 in the supplement), though the effect is modulated by temperature and salinity. We did not pursue statistical interpretation of the main effects of temperature, salinity, or chlorophyll, given the strong interaction term.

The osmotic content of clam tissue reliably tracked the osmotic content of the surrounding water at sam- 
pling Site 2. During fall 2010 and winter 2011 (i.e. Days of Year 300, 347, 14) prior to significant freshwater inputs the osmotic content of the habitat water was high and clam tissues were isosmotic with the water. However, during spring and summer 2011, when the osmotic content of bay water at Site 2 declined (Days of Year 90, 125, 145, 180, 208), clams hyper-regulated tissue osmolarity to $178 \pm 14 \mathrm{mOsm}$ $\mathrm{kg}^{-1}$ (Fig. 3).

Clam glycogen content at Site 2 varied through the year, from 7 to $21 \mathrm{~mol} \mathrm{~g}^{-1}$, reaching the highest values in December and early May and minimum values in late October (Fig. 2F). Clams sampled in December 2010 also had high glycogen content, though a month later in January 2011 glycogen dropped back to minimal levels.

Predicted filtration rates exhibited seasonal fluctuations and at most sites reached their highest values in January (Fig. 4). Lowest filtration rate values tended to occur in March, April, and May, though site-specific differences are apparent (Fig. 4). Clearance rates were calculated for Day 1 and Day 2 because they have the potential to provide different insights. Clearance rates based on Day 1 metabolic rates serve as some of the first 'field' measurements (or as close to field measurements as are currently possible) of clearance rates on individual clams. Clearance rates calculated from Day 2 metabolic rates are more likely to represent clearance rates necessary to meet basal needs under a given set of season-specific salinity and temperature conditions. However, there are no consistent differences in clearance rates calculated using Day 1 and Day 2 metabolic rates, except that the extremes observed in Day 1 clearance rates are muted in Day 2.

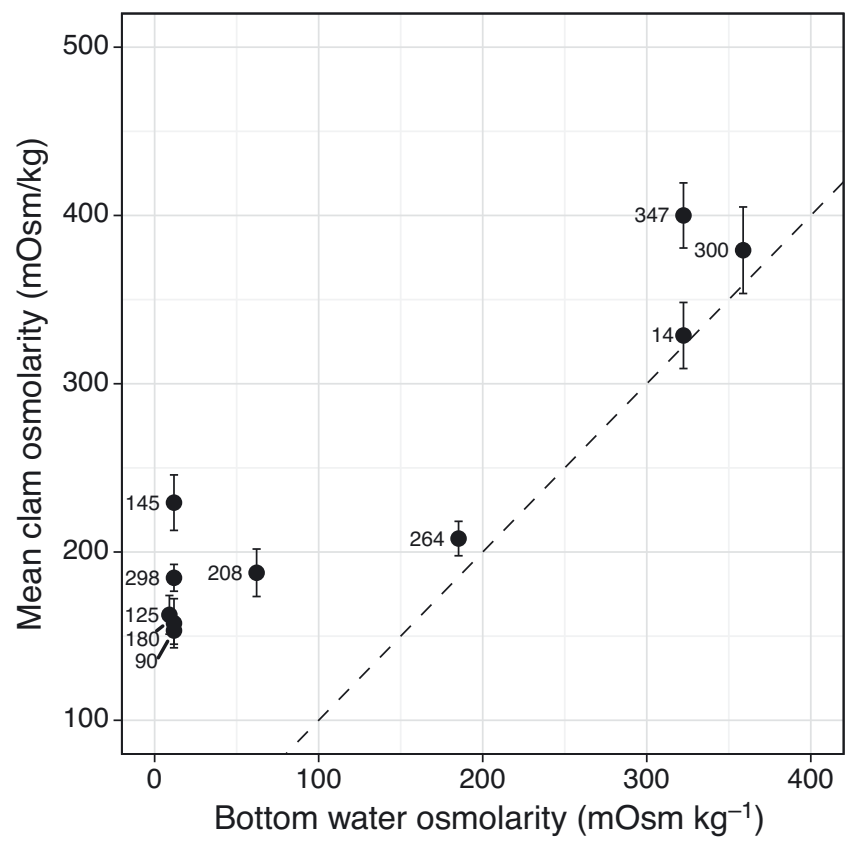

Fig. 3. Whole Corbula amurensis tissue osmolarity as a function of bottom water osmolarity. Values are mean $\pm \mathrm{SE}, \mathrm{n}=8$. Labels are the day of the year that clam and water samples were taken. Dashed line represents equivalence

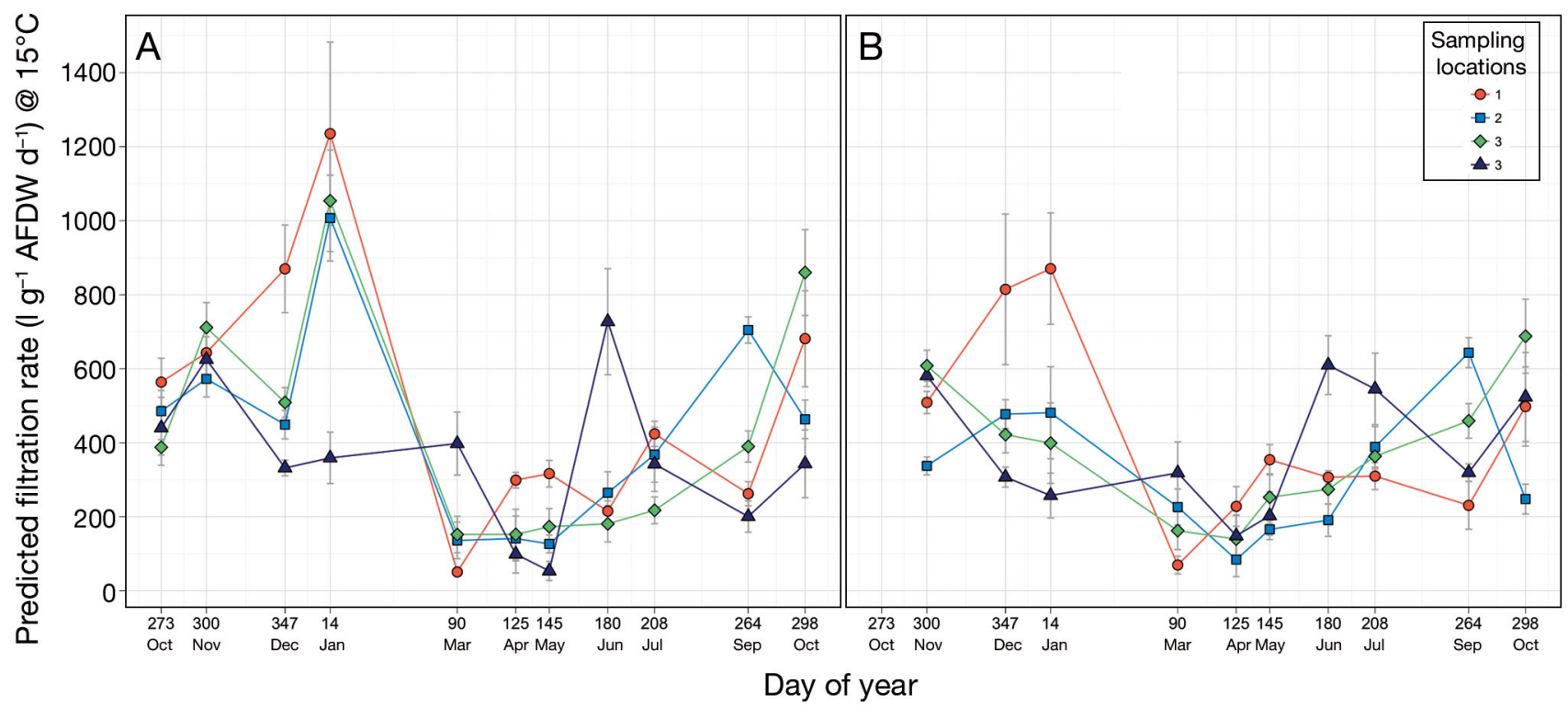

Fig. 4. Predicted Corbula amurensis filtration rates at $15^{\circ} \mathrm{C}$ as a function of the day of the year. Filtration rates were calculated for clams immediately following collection from the field (A, Day 1) and for the same clams after being held unfed in the laboratory for 1 day (B, Day 2) See 'Materials and methods - Predicted clam clearance rates' for a detailed description of how filtration rate was calculated. Values are means $\pm \mathrm{SE}, \mathrm{n}=10$ for each site and date 


\section{DISCUSSION}

Invasive species have the potential to dramatically alter native food webs by changing the pattern and rate of energy flow through invaded ecosystems. Identifying the impact of invasive species on native food webs (through energy diversion) and accurately associating increases in non-natives with concurrent declines in native species requires knowledge of the energy requirements of invasive species, and how sensitive energy use may be to environmental variation.

We measured metabolic rates of field-acclimatized specimens of the invasive clam Corbula amurensis in the San Francisco Estuary (SFE) over the course of a year. Limited tolerance to low salinity is often considered a primary determinate of $C$. amurensis distributions in the SFE because of the energetic costs associated with osmoregulating under such conditions. However, we found that salinity explained little of the seasonal change in metabolic demand, even though salinities at some sampling sites varied from 0.2 to 16 , and clam tissue osmolarities were regulated above that of the ambient water when exposed to low salinities. Such regulation would be expected to come at an energetic cost, but this was not reflected in higher metabolic rates or lower glycogen contents at low salinity. It is possible (though unlikely) that osmoregulation is not energetically costly. It is also possible that increased osmoregulatory costs, without an overall increase in metabolism, may result in decreased energy for other physiological processes such as growth or reproduction. Such energetic tradeoffs in response to environmental stress are common in bivalves (Petes et al. 2008) and often associated with food quality and availability (Bayne 2004, McClain et al. 2012).

One might also argue that salinity was not low enough for long enough in 2011 to see an effect of low salinity; however, monthly freshwater inflows during the spring of 2011 were high through July, exceeding freshwater inflows from the previous 3 years, and potentially keeping salinity low for an extended period (www.water.ca.gov/iep/products/ data.cfm) thus making 2011 a valuable year for detecting salinity-dependent energetic patterns.

Even with the addition of temperature and chl a concentration as explanatory variables, less than $20 \%$ of the variation in field metabolic rate (Day 1) was explained. The 3 -way model explained more variation (adjusted $\mathrm{R}^{2}=36 \%$ ) in Day 2 metabolic rates, suggesting that environmental variations better explain unfed, basal metabolism. The increased variation explained by the model for Day 2 rates suggests that clams were collected at different feeding states (satiated to unfed). However, measuring the same individuals in the same feeding state (unfed $24 \mathrm{~h}$ ) only increased the strength of the model approximately $16 \%$. This small increase in the explanatory power is not surprising given the potential reduction in feeding state related variation. However, after accounting for digestive processes, temperature, salinity, and chlorophyll maximally explain $36 \%$ of the variation in metabolic rate. We conclude that despite a statistically significant interactive effect of all 3 variables on clam metabolic rates, the biological importance of these environmental variables in determining clam metabolic rate is limited, and they are not primary drivers of clam energetics.

So what does this mean for the role that Corbula amurensis may play in the SFE? The calculated filtration rates agree with those reported by Cole et al. (1992) with C. amurensis feeding on phytoplankton in a flume at $15^{\circ} \mathrm{C}$. Converting maximal clearance rate estimates from Cole et al. (1992) $\left(200 \mathrm{ml}\right.$ ind.$\left.^{-1} \mathrm{~h}^{-1}\right)$ to AFDW (assuming $0.016 \mathrm{~g}$ AFDW ind. ${ }^{-1}$; Greene et al. 2011) gives maximum clearance rate estimates of $300 \mathrm{l} \mathrm{g}^{-1}$ AFDW d ${ }^{-1}$ at $15^{\circ} \mathrm{C}$ from Cole et al. (1992), which falls within the middle of the range of our estimates.

Our results lead to the somewhat unexpected finding that during the winter and early spring when chlorophyll levels are low, Corbula amurensis, despite having a lower metabolic rate, may have to filter much more water $\left(\sim 1000 \mathrm{l} \mathrm{g}^{-1}\right.$ AFDW d $\left.{ }^{-1}\right)$ in order to support their metabolism. This finding runs counter to the assumption that clams exert the greatest impact on the phytoplankton population during the summer when the water is warm and their metabolic rates are higher. It also reiterates the importance of the balance between 'supply' and 'demand' in determining the impact a species has on its environment. We recognize that we have quantified an individual clam effect, which may be moderated at the population level by the fact that clam abundances during the winter and early spring may be lower. The fact remains, however, that $C$. amurensis may be processing the overlying water column more vigorously during these cooler, but less prey rich, periods.

Together, our findings suggest some rather unexpected results. The first is that salinity, which has been widely regarded as the abiotic factor driving Corbula amurensis distributions and abundances in the SFE (primarily through the energetic cost of tolerating low salinities), may not play such a central role. If salinity, or even a salinity/temperature interaction, 
does not explain most of the variation in $C$. amurensis energetics it seems unlikely that these factors play a large role in the distribution patterns of the clam, at least as an adult. While adult $C$. amurensis are known to tolerate a wide range of salinities (2-30, Nicolini \& Penry 2000), newly fertilized embryos $(<2 \mathrm{~h}$ post-fertilization) tolerate a narrower range of salinities (between 10-30) before obtaining adult levels of salinity tolerance by $24 \mathrm{~h}$ post-fertilization (Nicolini \& Penry 2000). Thus, it may be that salinity plays the largest role in determining $C$. amurensis distributions in these very early stages. It is at least clear that as adults, C. amurensis energetics and the role they play in the ecosystem is largely independent of salinity (and chl a concentration) and only marginally related to temperature. As we incorporate C. amurensis energetics into energy models of the SFE across seasons salinity, and to the extent it is related, river outflow, may be of lesser importance.

The second finding, that the rate at which clams may impact the water column varies seasonally and may be highest in the winter and early spring, suggests that if these already resource-poor periods are important for other species they may be especially vulnerable to the presence of Corbula amurensis at times when these clams have been thought to be relatively unimportant. Further examination of the interaction between temperature, salinity, and food availability, with a recognition of the interaction between a species' requirements for, and the availability of, resources will be especially important as we seek to further clarify the role of $C$. amurensis in the San Francisco Estuary.

Acknowledgements. We thank X. Chen for her help with the glycogen and osmolarity measurements and W. Kimmerer for assistance in estimating clearance rates. We are grateful for a long list of volunteers as well as Captain D. Morgan and Marine Technician D. Bell who assisted in the field. We thank the anonymous reviewers who provided helpful comments on the manuscript. This research was supported by the United States Department of the Interior, Bureau of Reclamation, Cooperative Agreement Number R10AC20074.

\section{LITERATURE CITED}

Alpine AE, Cloern JE (1992) Trophic interactions and direct physical effects control phytoplankton biomass and production in an estuary. Limnol Oceanogr 37:946-955

> Anestis A, Lazou A, Portner HO, Michaelidis B (2007) Behavioral, metabolic, and molecular stress responses of marine bivalve Mytilus galloprovincialis during longterm acclimation at increasing ambient temperature. Am J Physiol Regul Integr Comp Physiol 293:R911-R921
Arar E, Collins GB (1993) In vitro determination of chlorophyll $a$ and phaeophytin $a$ in marine and freshwater phytoplankton by fluorescence - US EPA Method 445.0. National Exposure Research Laboratory, Office of Research and Development, US EPA, Cincinnati, $\mathrm{OH}$

Bayne BL (2004) Phenotypic flexibility and physiological tradeoffs in the feeding and growth of marine bivalve molluscs. Integr Comp Biol 44:425-432

> Berger VJ, Kharazova AD (1997) Mechanisms of salinity adaptations in marine molluscs. Hydrobiologia 355: 115-126

> Bricelj VM, Bass AE, Lopez GR (1984) Absorption and gut passage time of microalgae in a suspension feeder: an evaluation of the ${ }^{51} \mathrm{Cr}:{ }^{14} \mathrm{C}$ twin tracer technique. Mar Ecol Prog Ser 17:57-63

Carlton JT, Thompson JK, Schemel LE, Nichols FH (1990) Remarkable invasion of San Francisco Bay (California, USA) by the Asian clam Potamocorbula amurensis. I. Introduction and dispersal. Mar Ecol Prog Ser 66:81-94

Cloern JE (1982) Does the benthos control phytoplankton biomass in South San Francisco Bay? Mar Ecol Prog Ser 9:191-202

> Cole BE, Thompson JK, Cloern JE (1992) Measurement of filtration rates by infaunal bivalves in a recirculating flume. Mar Biol 113:219-225

Dukes JS, Mooney HA (2004) Disruption of ecosystem processes in western North America by invasive species. Rev Chil Hist Nat 77:411-437

Feyrer F, Nobriga ML, Sommer TR (2007) Multidecadal trends for three declining fish species: habitat patterns and mechanisms in San Francisco Estuary, California, USA. Can J Fish Aquat Sci 64:723-734

> Greene VE, Sullivan LJ, Thompson JK, Kimmerer WJ (2011) Grazing impact of the invasive clam Corbula amurensis on the microplankton assemblage of the northern San Francisco Estuary. Mar Ecol Prog Ser 431:183-193

Hutchinson S, Hawkins LE (1992) Quantification of the physiological responses of the European flat oyster Ostrea edulis L. to temperature and salinity. J Molluscan Stud 58:215-226

Kimmerer WJ (2002) Effects of freshwater flow on abundance of estuarine organisms: physical effects or trophic linkages? Mar Ecol Prog Ser 243:39-55

Kimmerer WJ, Gartside E, Orsi JJ (1994) Predation by an introduced clam as the likely cause of substantial declines in zooplankton of San Francisco Bay. Mar Ecol Prog Ser 113:81-93

> Kimmerer WJ, Gross ES, MacWilliams ML (2009) Is the response of estuarine nekton to freshwater flow in the San Francisco Estuary explained by variation in habitat volume? Estuar Coasts 32:375-389

- Kimmerer WJ, Parker AE, Lidstrom UE, Carpenter EJ (2012) Short-term and interannual variability in primary production in the low-salinity zone of the San Francisco Estuary. Estuar Coasts 35:913-929

> Marsden ID (2004) Effects of reduced salinity and seston availability on growth of the New Zealand little-neck clam Austrovenus stutchburyi. Mar Ecol Prog Ser 266: 157-171

> McClain CR, Gullet T, Jackson-Ricketts J, Unmack PJ (2012) Increased energy promotes size-based niche availability in marine mollusks. Evolution 66:2204-2215

> Navarro JM (1988) The effects of salinity on the physiological ecology of Choromytilus chorus (Molina, 1782) (Bivalvia: Mytilidae). J Exp Mar Biol Ecol 122:19-33 
Newell RIE (2004) Ecosystem influences of natural and cultivated populations of suspension-feeding bivalve molluscs: a review. J Shellfish Res 23:51-61

Nichols FH, Thompson JK, Schemel LE (1990) Remarkable invasion of San Francisco Bay (California, USA) by the Asian clam Potamocorbula amurensis. II. Displacement of a former community. Mar Ecol Prog Ser 66:95-101

Nicolini MH, Penry DL (2000) Spawning, fertilization, and larval development of Potamocorbula amurensis (Mollusca: Bivalvia) from San Francisco Bay, California. Pac Sci 54:377-388

Nobriga, ML, Sommer TR, Feyrer F, Fleming K (2008) Longterm trends in summertime habitat suitability for delta smelt (Hypomesus transpacificus). San Fran Estuar Watershed Sci 6:1-13. http://escholarship.org/uc/item/5xd3q8tx

Orsi JJ, Mecum WL (1996) Food limitation as the probable cause of a long-term decline in the abundance of Neomysis mercedis the opossum shrimp in the SacramentoSan Joaquin estuary. In: Hollibaugh JT (ed) San Francisco Bay: the ecosystem. AAAS, San Francisco, CA, p 375-401

Paganini A, Kimmerer WJ, Stillman JH (2010) Metabolic responses to environmental salinity in the invasive clam Corbula amurensis. Aquat Biol 11:139-147

Petes LR, Menge BA, Harris AL (2008) Intertidal mussels exhibit energetic trade-offs between reproduction and stress resistance. Ecol Monogr 78:387-402

Ricciardi A, Bourget E (1998) Weight-to-weight conversion factors for marine benthic macroinvertebrates. Mar Ecol Prog Ser 163:245-251

Richards JG, Heigenhauser GJF, Wood CM (2002) Glycogen phosphorylase and pyruvate dehydrogenase transformation in white muscle of trout during high-intensity exercise. Am J Physiol Regul Integr Comp Physiol 282: R828-R836

Sarà G, Romano C, Widdows J, Staff FJ (2008) Effect of salinity and temperature on feeding physiology and scope for growth of an invasive species (Brachidontes

Editorial responsibility: Gretchen Hofmann,

Santa Barbara, CA, USA
pharaonis-MOLLUSCA: BIVALVIA) within the Mediterranean sea. J Exp Mar Biol Ecol 363:130-136

Shumway SE, Koehn RK (1982) Oxygen consumption in the American oyster Crassostrea virginica. Mar Ecol Prog Ser 9:59-68

Sommer T, Armor C, Baxter R, Breuer R and others (2007) The collapse of pelagic fishes in the upper San Francisco Estuary. Fisheries (Bethesda) 32:270-277

Thompson JK (2005) One estuary, one invasion, two responses: Phytoplankton and benthic community dynamics determine the effect of an estuarine invasive suspension-feeder. In: Dame RF, Olenin S (eds) The comparative roles of suspension-feeders in ecosystems. NATO Sci Ser 4 Earth Environ Sci 47, Springer, Dordrecht, p 291-316

Thompson JK, Koseff JR, Monismith SG, Lucas LV (2008) Shallow water processes govern system-wide phytoplankton bloom dynamics: a field study. J Mar Syst 74: 153-166

> Werner I (2004) The influence of salinity on the heat-shock protein response of Potamocorbula amurensis (Bivalvia). Mar Environ Res 58:803-807

> Werner I, Hinton DE (1999) Field validation of hsp70 stress proteins as biomarkers in Asian clam (Potamocorbula amurensis): is downregulation an indicator of stress? Biomarkers 4:473-484

- Werner I, Hinton DE (2000) Spatial profiles of hsp70 proteins in Asian clam (Potamocorbula amurensis) in northern San Francisco Bay may be linked to natural rather than anthropogenic stressors. Mar Environ Res 50:379-384

Werner I, Hollibaugh JT (1993) Potamocorbula amurensis: comparison of clearance rates and assimilation efficiencies for phytoplankton and bacterioplankton. Limnol Oceanogr 38:949-964

Wilkerson FP, Dugdale RC, Hogue VE, Marchi A (2006) Phytoplankton blooms and nitrogen productivity in San Francisco Bay. Estuar Coasts 29:401-416

Submitted: April 10, 2012; Accepted: October 31, 2012 Proofs received from author(s): February 13, 2013 